\title{
Investigating the Aspects of Educating Students in Technical Universities
}

\section{Investigando los aspectos de la educación de estudiantes en universidades técnicas}

\author{
E.N. Karpanina \\ Kuban State Technological University, Krasnodar, Rusia \\ ORCID: https://orcid.org/0000-0002-5137-7567 \\ A. Yu. Gura* \\ Kuban State Technological University, Krasnodar, Rusia \\ ORCID: https://orcid.org/0000-0002-8111-7133
}

Recibido 02-10-19 Revisado 12-12-19 Aprobado 25-02-20 En línea 10-03-20

*Correspondencia

Email: gda-kuban@mail.ru
Citar como:

Karpanina, E. N., \& Gura, A. Yu. (2020). Investigating the Aspects of Educating Students in Technical Universities,

Propósitos y Representaciones, 8(3). doi:

http://dx.doi.org/10.20511/pyr2020.v8n3.471

(c) Universidad San Ignacio de Loyola, Vicerrectorado de Investigación, 2020. 


\section{Summary}

The article discusses the practical aspects of pedagogy that contribute to the success of the formation of civic education of students in the educational space of a technical university. The problems of the formation of civic education of students and the scientific coordination of the educational process in modern higher education are analyzed.

Keywords: Pedagogical Design; Pedagogical Conditions; Civil Culture of Students; Civil Education

\section{Resumen}

El artículo analiza los aspectos prácticos de la pedagogía que contribuyen al éxito de la formación de la educación cívica de los estudiantes en el espacio educativo de una universidad técnica. Se analizan los problemas de la formación de la educación cívica de los estudiantes y la coordinación científica del proceso educativo en la educación superior moderna.

Palabras clave: Diseño pedagógico; Condiciones pedagógicas; Cultura civil de los estudiantes; Educación civil

\section{Introduction}

It is known that in conditions of multidimensional social, economic and value changes in contemporary Russian reality, the priority goals and tasks of general and professional education are significantly overestimated. In the system of higher professional education, the tasks of the spiritual and creative development of students are brought to the fore by means of the integrated organization of the process of education and self-education on the basis of humanistic values and principles of general cultural development of the individual (Karpanina, 2004).

At the same time, the tasks of individualizing university education and differentiating the training of specialists, taking into account both the needs of students in the social and professional self-determination of the individual, and the social goals of self-realization of the specialist through activities unfolding in modern conditions are actualized.

Practical approbation of the program of civic education of students in the educational space of the technical university made it possible to single out a set of conditions in the composition: social pedagogical, didactic-methodological and acmeological.

The purpose of developing these conditions is the creation of a developing educational environment on the basis of the implementation of the interactive and creative basis of the teacher's professional and professional interactions with students. At the same time, it is to provide pedagogical support in the appearance of a person's civil formations in the students and an adequate pedagogical correction in this regard, organized in accordance with the sociopsychological structure of the individual's civic culture and proceeding from the content of the stages of civic education of the individual in training in the conditions of a technical university (Filonov, 2000).

In this regard, it is necessary, first of all, to make students aware of the meaning in their civic education and self-development. That is why the set of pedagogical conditions was primarily aimed at actualization and organization of procedural features and components of educational and cognitive activity, thereby putting them at the forefront for students. This helped not only the 
successful development of knowledge, but also the conscious personal acceptance of their students into their own spiritual-value sphere as a source for the development of civil beliefs, ideals and principles. As a result, a basis was laid for the manifestation of civic qualities in the personal orientation toward learning from scientific-theoretical and value-meaning positions (Sohrabi, 2017).

At the same time, the formation of socially valuable beliefs and socially directed attitudes of the future specialist's behavior was stimulated, and the development of analytical skills and methods of self-knowledge and self-regulation of the individual on the basis of a spiritual and moral comprehension of their ideals and principles was intensified.

\section{Methods}

Thus, under the conditions of a pedagogically supportive and civilizing educational environment organized by the teacher, the students have an increase in important parameters of the civil culture of the individual - civil reason, social responsibility, professional orientation of activities.

At the same time, the qualitative state of the integral parameters of civil culture in students is revealed through socio-pedagogical diagnostics (input, intermediate, final), developed by the teacher with the purpose of multidimensional characterization of the manifestations of civil culture. And this is precisely what is an important social and pedagogical condition that ensures the correspondence of target, substantive and procedural components of educational and cognitive activity, being at the same time a means of its social and pedagogical management.

Realizing the goals and objectives of civic education in the process of integrally mastering students the academic discipline, the basic content of the training material was specially interpreted by us in the unity of its civil and vocational-oriented principles.

Forming a socially and spiritually valuable worldview of the individual, the teaching material was mastered by the students in the unity of the scientific-theoretical and practicallysignificant aspects.

To do this, it was necessary to fill it with the emotional experience of learners of personal involvement in the values of the culture of their people and state, which contributed to the successful adoption of the traditions and ideals of culture and their "cultural transfer" into the individual spiritual and value sphere of the individual.

In turn, the teacher was important to help students in gaining personal conviction in the public significance of the forthcoming activity and to contribute to the development of positions of creative and responsible world transformation from future specialists on the basis of a personal need for independent activity in the implementation of acquired professional knowledge and skills. At the same time, pedagogical support for the growing creative activity of students was gradually consolidated in the independent civil position of the individual in terms of beliefs, views and assessments about the social significance of the specialist's activities.

Civic education of future specialists in the higher education system is influenced by a number of factors: professionally oriented learning activity, socially oriented interactions in the team and an active self-relationship of the individual during the period of study at the university (Karpanina \& Kuznetsova, 2007). The pedagogical design of the criterial model of civic education in the process of mastering the discipline by students is important to implement on the basis of an integral organization of the components of the university educational process (education and selfeducation, upbringing and self-education, etc.). 
The goal of civic education of specialists in the system of higher professional education in the conditions of a technical university includes the process of formation of the leading values and semantic positions of consciousness and self-consciousness that act monolithically with the actions and actions of the individual and do not allow it to alienate from the reality to which it belongs, And the prospects for the life of a future specialist and allow him to resolve his life in a civil society in a holistic and independent manner (Karpanina et al, 2018).

\section{Results}

The pedagogical achievement of the goal thus set occurs on the basis of the selection by the teacher of the means of developing educational content as part of the study by the future specialists of the mainstream discipline, on the one hand. On the other hand, on the basis of system and technological support for the implementation of this content in the process of using a comprehensive program that gives a step-by-step implementation to the solution of developmental learning tasks.

The main socio-pedagogical conditions for organizing the process of civic education in the conditions of a technical university are:

- complex diagnosis and assessment by the teacher of the dynamics of the emerging civic personality formation among students by means of social and pedagogical diagnostics, assessing the quality of knowledge on the subject, manifestations of ideological readiness in practice;

- the implementation of an adequate pedagogical correction, proceeding from the tasks of a system-holistic development of civic consciousness, self-awareness and behavior of future specialists.

Thus, on the basis of the advanced system-holistic design of the pedagogical model of civic education in the process of mastering the humanities knowledge by students, on the basis of its technological realization in selected pedagogical conditions (social pedagogical, didacticmethodological and acmeological), in the end.

As a result, the future specialist becomes capable not only of self-development of the leading parameters of the civil culture of the individual during the period of study at the university, but also to further personal improvement on the formed civic and value basis. And this gives personal meaning and ideological perspective of his professional activity aimed at protecting and preserving the spiritual and material traditions of Russian culture, popularizing and spreading the civil and moral ideals and values of his people, educating young generations of Russians in a patriotic and civil spirit.

\section{References}

Filonov, G. N. (2000). Education as a so-cio-pedagogical phenomenon. Development strategy. Moscow: State Research Institute for family and education Publ.

Karpanina, E. N. (2004). Civil education of students by means of architectural designing in conditions of high school: diss. ... cand. Ped.Sciences. Stavropol: SGU.

Karpanina, E. N., \& Kuznetsova, M. F. (2007). Architectural design as a means of teaching and educating students of humanitarian universities: Proc. Allowance. In 2 parts. Part 2. Stavropol.

Karpanina, E. N., Gura, A. Yu., \& Ron, I. N. (2018). Rationale of the system approach to education of future specialists in the university. Astra Salvensis, 6(1), 763-765. 